\title{
Fiscaoeconomia
}

Journal Homepage: dergipark.gov.tr/fsecon

\section{The Behaviour of Interest Rates in Turkey}

\section{Faiz Oranlarının Türkiye'deki Davranışı}

\section{Onur SUNAL ${ }^{1}$}

Article Info

Article History:

Date Submitted: 13.12 .2019

Date Accepted: 16.01.2020

Jel Classification:

$E 43, E 58, C 22$

Keywords:

Short Term Interest Rates, Market Interest Rates,

Central Banks,

Error Correction Model,

Pass Through Effect
Abstract

Short term interest rates are one of the most influential monetary policy tools for contemporary central banks. More often they are used to prompt the monetary transmission mechanism either to avoid recessions or to control the rising prices via affecting the market interest rates. The main aim of this study is to investigate the relationships among short term and other types of market interest rates in Turkey. Monthly data on short term interest rates set by the Turkish Central Bank, benchmark market interest rates on Turkish 2 year Treasury Bonds and bank lending and bank deposit rates are used in this study covering the period between 2012(M06) and 2019(M09). The relationships between the variables are investigated by adopting co-integration and error correction models. The results revealed that there is a strong significant co-movement between short term and other market interest rates. As the findings of error correction models revelaed a percent change in short term rates are accompanied by a 0.86 percent change in lending and 0.76 percent change in deposit rates.

\section{1-Introduction}

Interest rates or more precisely the yield to maturity reflects the cost of borrowing for those who are short of funds and reflects the rate of return for those who have excess of funds. Moreover the determination and the behaviour of interest rates has always attracted both academic and public attention as they are widely accepted as one of the most important key macro economic and financial variables among many other indicators. Even though they are used as a single term presented in percentages that captures the whole relationship underlined above, there are various different types of interest rates in reality. Therefore it is important to distiguish these different types of interest rates to be able to explain the behaviour and the movement of them.

\footnotetext{
${ }^{1}$ Doç.Dr., Başkent Üniversitesi, TBF, Bankacılık ve Finans Bölümü, osunal@ baskent.edu.tr
} 
The short term interest rates (overnight rates) mainly represent the burden of acquiring reserves for depository institutions who are short of funds either for daily payment dues as a result of deposit outflows or for meeting required reserve obligations set by the authorities. These short term interest rates usually fluctuate between a narrow band (corridor) which is set and controlled by the central banks. Also the "policy rate" which is referred to as the target rate lies in between the upper and lower bound of the short term interest rate channel. Another important interest rate which shows the bond market dynamics is the "benchmark" rate (gösterge faiz) on bonds that are traded widely in the secondary markets and have very high liquidity. In Turkey the yield on Treasury Bond (sovereign debt instrument) that has a 2 year term to maturity is considered as the market interest rate. The rate on sovereign bonds for 5 or 10 years to maturity generally reveals the long term rates. These market rates on sovereign debt are crucial for the construction of yield curves that represent the term structure of interest rates. Publicly the interest charged by banks on loans (commercial, consumer, mortgage and others) and the interest paid to collect deposits are often the ones that individuals are more familiar with which are also closely monitored by all economic agents.

These different types of interest rates are related to each other in such a way that they usually follow a similiar trend. In other words it is assumed that there is an important pass through effect from the short term rates towards the market and bank interest rates which also demonstrates the path of and significance of the monetary transmission mechanism. In the relevant literature there are numerous amount of studies which capture these relationships. Some studies (Aziakpono and Wilson, 2013; Bennouna, 2019) focus on the fact that whether there is a complete or an incomplete pass through effect. Andries and Billon (2016) found an incomplete pass through effect from short term policy rates to deposit rates and a close long term effect to lending rates in Euro Zone for pre-2008 period. The relationship whether changes or remains the same during periods of financial distress (Aristei and Gallo, 2014; Illes and Lombardi, 2013) or accross countries (Belke, Beckman and Verheyen, 2013; Illes, Lombardi and Mizen, 2015) were also studied. Hence asymmetry (Karagiannis, 2010) was found to be prevalent when EU and US were to be compared. On the other hand some studies focused more on the degree of pass through between lending and deposit rates where a faster and more greater effect was observed in favour of the lending rates (Kwapil and Scharler, 2013; Muhammad, 
2011; Stanislawska, 2015, Mello and Pisu, 2010). Moreover, a stream of other papers emphasized factors more related to the structure (Disyatat, 2011), market concentration (Holton and D'Acri, 2018), overall profitability (Gunji and Yuan, 2010) and capital structure (Breitenlechner, Scharler and Sindermann, 2016) of the banking system. In the same manner there are also studies in the domestic literature capturing and exploring the similar relationships (Binici, Kara and Özlü, 2016; Uslu and Karahan, 2016). As a result the investigaton of the relationships among the interest rates (short term, benchmark market rate, lending and deposit rate) explained briefly above by utilizing an error correction model using monthly data for 2012/M06 and 2019/M09 period is aimed in this study where data and methodology, findings and conclusion will follow this introduction section.

\section{Data and Methodolgy}

The monthly time series data for short term interest rates which are the average funding costs of banks on borrowed reserves as set and controlled by central bank (FF), the benchmark market interest rates (yield) on two year Turkish Treasury Bonds (GT), lending rates (TKT) and deposit rates (MVD) for Turkish Banking Sector were obtained from The Turkish Central Bank's electronic data system (EVDS). The data covers the period between 2012/M06 and 2019/M09. Also the following methodological framework is used as outlied below.

The stationarity of series in time series analysis is important as spurious regressions with high goodness of fit values might lead to misjudgements and misinterpretations of obtained regression results if series are non-stationary or in other words have unit roots. Therefore to outrule this possibility of a spurious regression, stationarity of series should be tested and verified. Unit root tests such as the Augmented Dickey and Fuller (1981) should be conducted to see whether the series are stationary or not on their own levels often referred to as representing an I (0) process. When the series are non-stationary then the series might be differenced to capture whether stationarity exits on their first I(1) or higher order levels.

If all the series become stationary integrated on the same order level then vector error correction models (VECM) might be run to reveal both the long and short run dynamics. First the lag lenght of the VAR (Vector Auto Regressive) model should be determined using the relevant lag selection criteria such as the LR (modified Likelihood Ratio Statistic), FPE (Final Prediction 
Error), AIC (Akaike Information Criterion, SC (Schwarz Information Criterion) and HQ (Hannan-Quinn Information Criterion) . The next step involves finding whteher the series are co-integrated or not. Johansen and Jeselius (1990) co-integration procedure is widely used for this purpose where Maximum Eigenvalue and Trace test statistics are used which shows the rank of the cointegrating vectors. The rank of co-integration will provide the number of equations to consider. Finally the VECM can be constructed.

In this study three seperate VECM will be constructed. The first one will be between short term interest rates (FF) and market interest rates (GT), second one between (FF) and bank lending rates (TKT) and the third one between (FF) and bank deposit rates (MVD).

\section{3-Findings}

Table 1: ADF Unit Root Test Results of Variables on Their Own Levels

\begin{tabular}{|c|c|c|c|c|c|c|c|c|c|c|c|c|}
\cline { 2 - 13 } & \multicolumn{3}{c|}{ GT } & \multicolumn{3}{c|}{ FF } & \multicolumn{3}{c|}{ MVD } & \multicolumn{3}{c|}{ TKT } \\
\cline { 2 - 13 } & None & C. & C. /T. & None & C. & C. /T. & None & C. & C. /T. & None & C. & C./T. \\
\hline ADF Test St. & -0.514 & -1.860 & -3.089 & 0.409 & -0.763 & -1.712 & 1.331 & 0.731 & 1.326 & 0.693 & 0.008 & 1.949 \\
\hline P Value & 0.491 & 0.349 & 0.115 & 0.799 & 0.824 & 0.737 & 0.952 & 0.992 & 0.873 & 0.863 & 0.956 & 0.618 \\
\hline Critic Values & & & & & & & & & & & & \\
\hline $\mathbf{1 \%}$ & -2.590 & -3.504 & -4.063 & -2.590 & -3.503 & -4.062 & -2.595 & -3.517 & -4.081 & -2.595 & -3.517 & -4.081 \\
\hline $\mathbf{5 \%}$ & -1.944 & -2.893 & -3.460 & -1.944 & -2.893 & -3.459 & -1.945 & -2.899 & -3.469 & -1.945 & -2.899 & -3.469 \\
\hline $\mathbf{1 0 \%}$ & -1.614 & -2.584 & -3.156 & -1.614 & -2.583 & -3.156 & -1.614 & -2.587 & -3.161 & -1.614 & -2.587 & -3.161 \\
\hline
\end{tabular}


Table 2. ADF Unit Root Test Results of Variables on Their First Differences

\begin{tabular}{|c|c|c|c|c|c|c|c|c|c|c|c|c|}
\cline { 2 - 12 } & \multicolumn{3}{c|}{ D(GT) } & \multicolumn{3}{c|}{ D(FF) } & \multicolumn{3}{c|}{ D(MVD) } & \multicolumn{3}{c|}{ D(TKT) } \\
\cline { 2 - 12 } & None & C. & C./T. & None & C. & C. /T. & None & C. & C. /T. & None & C. & C. /T. \\
\hline ADF Test St. & -6.680 & -6.642 & -6.594 & -7.769 & -7.732 & 7.712 & -7.902 & -8.007 & -8.393 & -7.440 & -7.445 & -7.990 \\
\hline P Value & 0.000 & 0.000 & 0.000 & 0.000 & 0.000 & 0.000 & 0.000 & 0.000 & 0.000 & 0.000 & 0.000 & 0.000 \\
\hline Critic Values & & & & & & & & & & & & \\
\hline $\mathbf{1 \%}$ & -2.590 & -3.504 & -4.063 & -2.590 & -3.504 & -4.063 & -2.595 & -3.519 & -4.083 & -2.595 & -3.519 & -4.083 \\
\hline $\mathbf{5 \%}$ & -1.944 & -2.893 & -3.460 & -1.944 & -2.893 & -3.460 & -1.945 & -2.900 & -3.470 & -1.945 & -2.900 & -3.470 \\
\hline $\mathbf{1 0 \%}$ & -1.614 & -2.584 & -3.156 & -1.614 & -2.584 & -3.156 & -1.613 & -2.587 & -3.161 & -1.613 & -2.587 & -3.161 \\
\hline
\end{tabular}

As it can be seen from Table 1 all series have unit roots on their own levels as p-values are significantly higher than 0.05 percent. Table 2 shows that when series are differenced once all series become stationary.

Table 3. Lag Length Criteria Results for Variables FF and GT

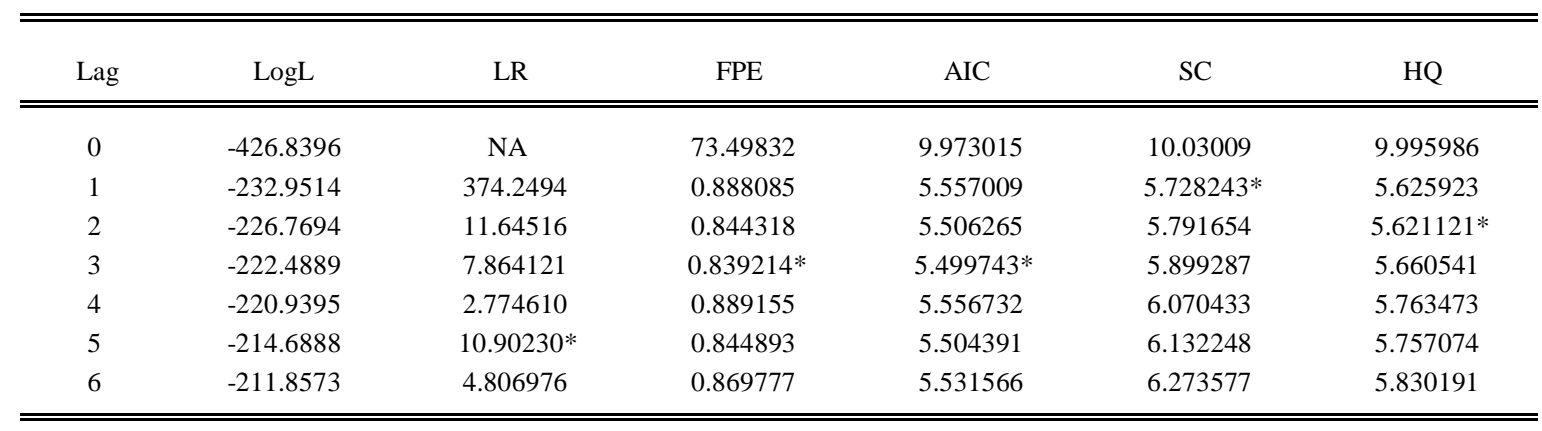

Table 4. Lag Length Criteria Results for Variables FF and TKT

\begin{tabular}{|c|c|c|c|c|c|c|}
\hline Lag & $\log \mathrm{L}$ & LR & FPE & AIC & $\mathrm{SC}$ & HQ \\
\hline 1 & -288.4039 & 368.2730 & 2.560274 & 6.615817 & 6.783591 & 6.683442 \\
\hline 2 & -254.4237 & $64.14243 *$ & $1.305502 *$ & $5.942105^{*}$ & $6.221727^{*}$ & $6.054812 *$ \\
\hline 3 & -251.2733 & 5.805247 & 1.331217 & 5.961197 & 6.352668 & 6.118987 \\
\hline
\end{tabular}

* indicates lag order selected by the criterion

LR: sequential modified LR test statistic (each test at 5\% level)

FPE: Final prediction error

AIC: Akaike information criterion

SC: Schwarz information criterion

HQ: Hannan-Quinn information criterion 
Table 5. Lag Length Criteria Results for Variables FF and TKT

\begin{tabular}{ccccccc}
\hline \hline Lag & LogL & LR & FPE & AIC & SC & HQ \\
\hline \hline 1 & -225.2052 & NA & 0.627175 & 5.209209 & 5.321816 & 5.254576 \\
2 & -211.3923 & $26.37019^{*}$ & $0.501856^{*}$ & $4.986188^{*}$ & $5.211400^{*}$ & $5.076920^{*}$ \\
3 & -210.2887 & 2.056616 & 0.536164 & 5.052016 & 5.389835 & 5.188115 \\
4 & -207.3657 & 5.314606 & 0.549770 & 5.076492 & 5.526917 & 5.257957 \\
\hline \hline
\end{tabular}

Tables 3, 4 and 5 represent the optimum lag lenghts for 3 separate models. Optimum lag length for model one (FF-GT) is three, for model two (FF-TKT) and model three (FF-MVD) the lag length should be two according to the relevant information criteria.

Table 6. Selected (0.05 level*) Number of Cointegrating Relations by Model (FF-GT)

\begin{tabular}{cccccc}
\hline \hline Data Trend: & None & None & Linear & Linear & Quadratic \\
\hline Test Type & No Intercept & Intercept & Intercept & Intercept & Intercept \\
& No Trend & No Trend & No Trend & Trend & Trend \\
Trace & 0 & 1 & 1 & 1 & 2 \\
Max-Eig & 0 & 1 & 1 & 1 & 2 \\
\hline \hline
\end{tabular}

*Critical values based on MacKinnon-Haug-Michelis (1999)

Table 7. Selected (0.05 level*) Number of Cointegrating Relations by Model (FF-TKT)

\begin{tabular}{cccccc}
\hline \hline \multirow{2}{*}{ Data Trend: } & None & None & Linear & Linear & Quadratic \\
\hline Test Type & No Intercept & Intercept & Intercept & Intercept & Intercept \\
& No Trend & No Trend & No Trend & Trend & Trend \\
Trace & 0 & 1 & 1 & 1 & 2 \\
Max-Eig & 0 & 1 & 1 & 1 & 2 \\
\hline \hline * Critical values based on MacKinnon-Haug-Michelis (1999)
\end{tabular}

*Critical values based on MacKinnon-Haug-Michelis (1999)

Table 8. Selected (0.05 level*) Number of Cointegrating Relations by Model (FF-MVD)

\begin{tabular}{cccccc}
\hline \hline Data Trend: & None & None & Linear & Linear & Quadratic \\
\hline Test Type & No Intercept & Intercept & Intercept & Intercept & Intercept \\
& No Trend & No Trend & No Trend & Trend & Trend \\
Trace & 0 & 1 & 1 & 1 & 2 \\
Max-Eig & 0 & 1 & 1 & 1 & 2 \\
\hline \hline
\end{tabular}

*Critical values based on MacKinnon-Haug-Michelis (1999)

It can clearly be seen from Tables 6,7 and 8 that for all models the majority of data trends provide one cointegrating relations. In this study I use linear data trend with intercept and and no trend. 
Table 9. VECM Estimates for FF-GT Model (model 1)

\begin{tabular}{ccc}
\hline \hline Cointegrating Eq: & CointEq1 & \\
\hline \hline FF(-1) & 1.000000 & \\
GT(-1) & $\begin{array}{r}-1.306725 \\
(0.05818) \\
{[-22.4586]}\end{array}$ & \\
& 3.644688 & \\
C & $\mathrm{D}(\mathrm{FF})$ & $\mathrm{D}(\mathrm{GT})$ \\
\hline \hline Error Correction: & -0.225354 & 0.184077 \\
& $(0.08536)$ & $(0.12080)$ \\
CointEq1 & {$[-2.64002]$} & {$[1.52382]$} \\
& $0.01^{*}$ & \\
\hline \hline
\end{tabular}

Standard errors in ( ) \& t-statistics in [ ] and * for p values

$-0.22\left(\mathrm{FF}_{\mathrm{t}-1}-1.30 \mathrm{GT}_{\mathrm{t}-1}+3.64\right)$ co-integration equation for model 1

Table 10. VECM Estimates for FF-TKT Model (model 1)

\begin{tabular}{ccc}
\hline \hline Cointegrating Eq: & CointEq1 & \\
\hline \hline TKT(-1) & 1.000000 & \\
& & \\
FF(-1) & -0.865926 & \\
& $(0.06936)$ & \\
& {$[-12.4841]$} & \\
C & -7.480875 & \\
\hline \hline Error Correction: & $\mathrm{D}(\mathrm{TKT})$ & $\mathrm{D}(\mathrm{FF})$ \\
\hline \hline \multirow{2}{*}{ CointEq1 } & -0.275571 & 0.074195 \\
& $(0.06531)$ & $(0.05762)$ \\
& {$[-4.21929]$} & {$[1.28770]$} \\
& $0.0001 *$ & \\
\hline \hline
\end{tabular}

Standard errors in ( ) \& t-statistics in [ ] and * for p values 
Table 11. VECM Estimates for FF-MVD Model (model 3)

\begin{tabular}{ccc}
\hline \hline Cointegrating Eq: & CointEq1 & \\
\hline \hline MVD(-1) & 1.000000 & \\
& & \\
FF(-1) & -0.760809 & \\
& $(0.02791)$ & \\
& {$[-27.2630]$} & \\
C & -2.168718 & \\
\hline \hline \multirow{2}{*}{ Error Correction: } & D(MVD) & D(FF) \\
\hline \hline \multirow{2}{*}{ CointEq1 } & -0.491493 & -0.203439 \\
& $(0.10274)$ & $(0.14841)$ \\
& {$[-4.78367]$} & {$[-1.37077]$} \\
& $0.0001 *$ & \\
\hline \hline
\end{tabular}

$-0.49\left(\mathrm{MVD}_{\mathrm{t}-1}-0.76 \mathrm{FF}_{\mathrm{t}-1}-2.16\right)$ co-integration equation for model 3

Tables 9, 10 and 11 show the results of the VECM estimates. For all three models error correction coefficients are negative $(-0.22,-0.27$ and -0.49 respectively) which means that the variables converge to their long run equilibriums systematically whenever they depart. As the data is monthly it almost takes around 4 months to converge for the first two models and 2 months for the third model. Moreover all the coefficients are statistically significant even at 0.01 level. The error correction equations (1), (2) and (3) demonstrate that every percent change in market interest rates (GT) are accompanied with a 1.30 percent change in short term interest rates $(\mathrm{FF})$, and every perent change in FF leads to 0.86 percent change in lending rates (TKT) and 0.76 percent change in deposit rates (MVD).

Table 12. Harvey Heteroscedasticity Test for FF-GT Model (model 1)

\begin{tabular}{llll}
\hline \hline F-statistic & 1.364769 & Prob. F(8,79) & 0.2250 \\
Obs*R-squared & 10.68524 & Prob. Chi-Square(8) & 0.2202 \\
Scaled explained SS & 12.53437 & Prob. Chi-Square(8) & 0.1289 \\
\hline \hline
\end{tabular}

Table 13. Harvey Heteroscedasticity Test for FF-TKT Model (model 2)

\begin{tabular}{llll}
\hline \hline F-statistic & 1.720651 & Prob. F(6,82) & 0.1265 \\
Obs*R-squared & 9.952216 & Prob. Chi-Square(6) & 0.1267 \\
Scaled explained SS & 9.723552 & Prob. Chi-Square(6) & 0.1368 \\
\hline \hline
\end{tabular}


Table 14. Harvey Heteroscedasticity Test for FF-MVD Model (model 3)

\begin{tabular}{llll}
\hline \hline & & & \\
F-statistic & 1.683102 & Prob. F(6,82) & 0.1355 \\
Obs*R-squared & 9.758852 & Prob. Chi-Square(6) & 0.1352 \\
Scaled explained SS & 7.218847 & Prob. Chi-Square(6) & 0.3011 \\
\hline \hline
\end{tabular}

Table 15. Breusch - Godfrey LM Serial Correlation Test for FF-GT Model (model 1)

\begin{tabular}{|c|c|c|c|}
\hline F-statistic & 1.479695 & Prob. F $(3,77)$ & 0.2267 \\
\hline Obs*R-squared & 4.796707 & Prob. Chi-Square(3) & 0.1873 \\
\hline
\end{tabular}

Table 16. Breusch - Godfrey LM Serial Correlation Test for FF-TKT Model (model 2)

\begin{tabular}{llll}
\hline \hline F-statistic & 0.451388 & Prob. F(2,81) & 0.6383 \\
Obs*R-squared & 0.981006 & Prob. Chi-Square(2) & 0.6123 \\
\hline \hline
\end{tabular}

Table 17. Breusch - Godfrey LM Serial Correlation Test for FF-MVD Model (model 3)

\begin{tabular}{llll}
\hline \hline F-statistic & 0.351675 & Prob. F(2,81) & 0.7046 \\
Obs*R-squared & 0.766163 & Prob. Chi-Square(2) & 0.6818 \\
\hline \hline
\end{tabular}

Tables 12-17 demonstrate the results of the post-estimation tests. The test results show that the null hypothesis of no serial correlation for Breusch - Godfrey LM Test and the null hypothesis of no heteroscedasticity for Harvey test can not be rejected for all three models. Therefore the residiuals are not serially correlated with no heteroscedasticity which are statistically desired properties for the validitiy of these models.

Graph 1. CUSUM Test for Model 1

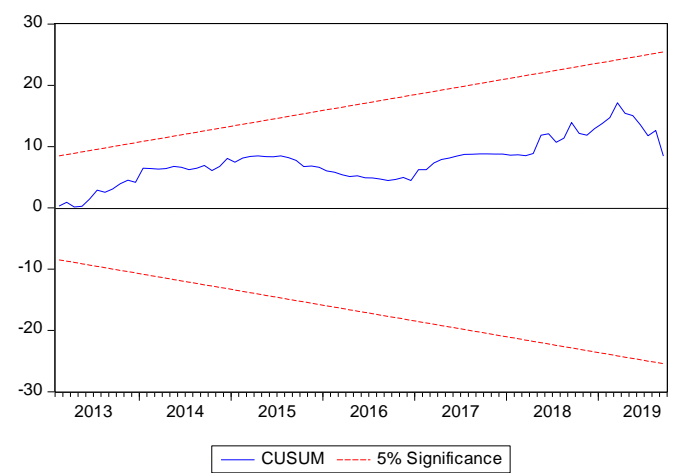

Graph 2. CUSUM Test for Model 2

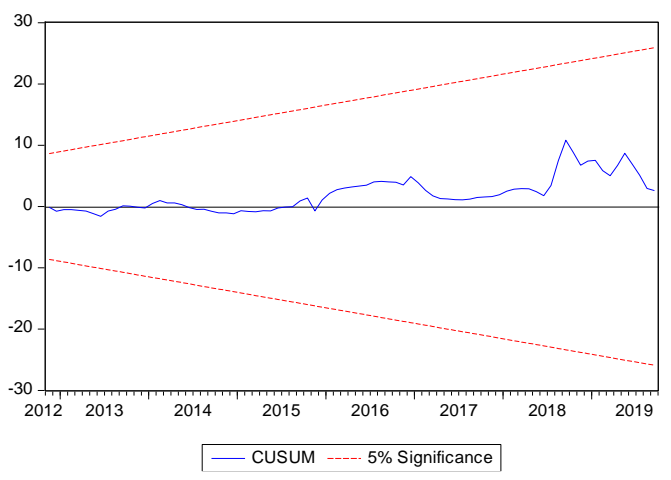


Graph 3. CUSUM Test for Model 3

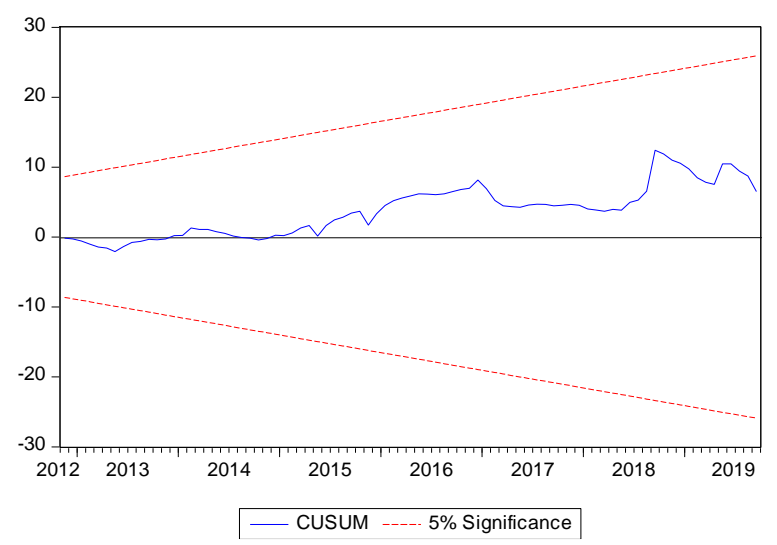

It can be seen from the graphs of structural stability tests (cusum) that the graphs for the recursive estimates both lie within the confidence bands which displays the parameter stability for the model.

\section{Conclusion}

The main aim of this study was to investigate the behaviour of interest rates in Turkey during 2012 and 2019. Both in theory and in practice it is widely assumed that interest rates do somehow prevail a common pattern or follow a similar trend even if not identical. The magnitude and the speed of transition from short term interest rates to market and bank interest rates are of great concern especially for the monetary policy makers as it is an important sign of the strenght of the monetary transmission mechanism. Otherwise without the absence of a pass through between the short and long run interest rates the monetary policy tools used by the central banks will nevertheless become ineffective.

In this study by using co-integration and error correction analysis some features of the movement of interest rates are revelaed. First of all there is a significant relationship between short term interest rates (FF) and market interest rates (GT). Moreover the direction of the relationship is from the FF to GT which basicaly indicates that rather market interest rates determine the changes in short term interest rates set by The Central Bank. In other words it seems that The Central Bank adopts a reactive policy approach rather than a pro-active one in Turkey which signals that the mechanism is driven by market forces. As the error correction 
model results diplay there is a strong and signifiant relationship where a $1 \%$ change in GT is accompanied by a $1.30 \%$ change in FF.

Also in this paper it is found that the changes in short term interest rates causes changes in both lending and deposit rates of banks which reflects the presence of a strong pass through effect as the coefficients were all significant and close to unity ( 0.86 for lending rates TKT and 0.76 for deposit rates MVD repectively). An important feature of this finding is that banks tend to pass changes in short term interest rates to lending rates (TKT) more than they pass to deposit rates (MVD) which widens the interest margin when short term rates rise and narrows when short term rates fall. This might well be explained by the fact that especially when the short term rates are rising banks' perceived level of risk increases which leads to a rise in lending rates. Also the cost of holding deposits also rise as a result of depositors' higher inflationary expectations if the transmission mechanism is driven by the persistent rises in current price levels.

\section{References}

Andries, N., Billon, S. (2016). "Retail bank interest rate pass-through in the euro area: An empirical survey", Economic Systems, 40, 170-194.

Aristei, D., Gallo, M. (2014). "Interest rate pass-through in the Euro area during thefinancial crisis: A multivariate regime-switching approach”, Journal of Policy Modelling, (36), 273-295.

Aziakpono, M.J. (2013). "Interest Rate Pass-through and Monetary Policy Regimes in South Africa”, AERC Research Paper, (no. 259), 1-67.

Bennouna, H. (2019). "Interest rate pass-through in Morocco: Evidence from bank-level survey data", Economic Modelling, (80), 142-157.

Belke, A., Beckmann, J. and Verheyen, F. (2013). "Interest rate pass-through in the EMU New evidence from nonlinear cointegration techniques for fully harmonized data", Journal of International Money and Finance, (37), 1-24.

Binici, M., Kara, H. and Özlü, P. (2016). "Unconventional Interest Rate Corridor and the Monetary Transmission: Evidence from Turkey", TCMB Working Paper, (16/8), 1-36. 
Breitenlechner, M., Scharler, J. and Sindermann, F. (2016). "Banks' external financing costs and the bank lending channel:Results from a SVAR analysis ", Journal of Financial Stability, (26), 228-246.

Dickey, D.A., Fuller, W.A. (1981).” Likelihood Ratio Statistics for Autoregressive Time Series With A Unit Root”, Econometrica, 49(4), 1057-1072.

Disyatat, P. (2011). "The Bank Lending Channel Revisited”, Journal of Money, Credit and Banking, 43(4),

Gunji, H. Yuan, Y. (2010). "Bank profitability and the bank lending channel: Evidence from China”, Journal of Asian Economics, (21), 129-141.

Holton, S., D'Acri, C.R. (2018). "Interest rate pass-through since the euro area crisis", Journal of Banking and Finance, (96), 277-291.

Illes, A., Lombardi, M. (2013). "Interest rate pass-through since the financial crisis", BIS Quarterly Review, (September), 57-66.

Illes, A., Lombardi, M. And Mizen, P. (2015). "Why did bank lending rates diverge from policy rates after the financial crisis?", BIS Working Papers, (486), 1-31.

Johansen, S., Juselius, K. (1990). "Maximum Likelihood Estimation and Inference on Cointegration - With Applications to The Demand for Money", Oxford Bulletin of Economics and Statistics, 52(2), 169-210.

Karagiannis, S., Panagopoulos, Y. and Vlamis, P. (2010). "Interest rate pass-through in Europe and the US: Monetary policy after the financial crisis", Journal of Policy Modelling, (32), 323-338.

Kwapil, C., Scharler, J. (2013). "Expected monetary policy and the dynamics of bank lending rates", International Review of Economics and Finance", (27), 542-551.

Mello, L., Pisu, M. (2010). "The bank lending channel of monetary transmission in Brazil: A VECM approach", Quarterly Review of Economics and Finance, (50), 50-60.

Muhammad, H.M. (2011). "Impact of monetary policy on lending and deposit rates in Pakistan: Panel data analysis", MPRA no. 33301.

Stanislawska, E. (2015). "Interest Rate Pass-Through in Poland: Evidence from Individual Bank Data”, Eastern European Economics, 53(1), 3-24. 
Uslu, N.Ç., Karahan, P. (2016). "Para Politikasının Kredi Faiz Oranlarına Geçişkenliği Üzerine Dinamik Bir Analiz: Türkiye Örneği’”, Yönetim ve Ekonomi, 23(3), 671-690. 